\title{
Penerapan Model Pembelajaran Penemuan Berbantuan Simulasi Phet Untuk Meningkatkan Keterampilan Inkuiri Dan Hasil Belajar Peserta Didik Kelas X MIA 1 SMAN 1 Wonggeduku Pada Materi Pokok Gerak Parabola
}

\author{
Yeyen Atusman Mangidi ${ }^{1 *}$, Luh Sukariasih ${ }^{2)}$, Vivi Hastuti Rufa Mongkito ${ }^{3)}$ \\ 1)* Mahasiswa Jurusan Pendidikan Fisika Fakultas Keguruan dan Ilmu Pendidikan UHO \\ ${ }^{2), 3)}$ Dosen Jurusan Pendidikan Fisika Fakultas Keguruan dan Ilmu Pendidikan UHO \\ *Koresponden Email: yeyenatusman@gmail.com
}

\begin{abstract}
Abstrak: Penelitian ini bertujuan untuk : 1) mengetahui gambaran keterampilan inkuiri pesera didik kelas X MIA 1 SMAN 1 Wonggeduku pada materi pokok gerak parabola yang diajar dengan model pembelajaran penemuan berbantuan simulasi PhET; 2) mengetahui besar peningkatan hasil belajar pesera didik kelas X MIA 1 SMAN 1 Wonggeduku pada materi pokok gerak parabola yang diajar dengan model pembelajaran penemuan berbantuan simulasi PhET; dan 3) mengetahui gambaran ketuntasan hasil belajar peserta didik kelas X MIA 1 SMAN 1 Wonggeduku pada materi pokok gerak parabola setelah diajar dengan model pembelajaran penemuan berbantuan simulasi PhET. Jenis penelitian ini adalah penelitian tindakan kelas (PTK) yang telah dilaksanakan dalam 2 (dua) siklus. Subjek dalam penelitian ini adalah seluruh peserta didik kelas X MIA 1 SMAN 1 Wonggeduku tahun ajaran 2018/2019 yang berjumlah 25 orang. Data yang dikumpulkan pada penelitian ini adalah keterampilan inkuiri yang diperoleh dari lembar observasi dan hasil belajar yang diperoleh dari tes hasil siklus I dan siklus II. Analisis data yang dilakukan statistik deskriptif. Dari hasil analisis data diperoleh kesimpulan bahwa: 1) keterampilan inkuiri peserta didik kelas X MIA 1 SMAN 1 Wonggeduku pada materi pokok gerak parabola melalui penggunaan model pembelajaran penemuan berbantuan simulasi PhET mengalami peningkatan. Hal ini ditunjukkan dengan skor rata-rata aspek keterampilan inkuiri peserta didik pada siklus I dan siklus II. Dimana pada siklus I diperoleh skor rata-rata sebesar 2,2 yang berada pada kategori cukup dan pada siklus II diperoleh skor rata-rata sebesar 3,3 yang berada pada kategori baik; 2) hasil belajar peserta didik kelas X MIA 1 SMAN 1 Wonggeduku yang diajar dengan menggunakan model pembelajaran penemuan berbantuan simulasi PhET pada materi pokok gerak parabola mengalami peningkatan. Hal ini ditunjukkan pada siklus I diperoleh nilai mulai rata-rata sebesar 61,8 dan pada siklus II diperoleh nilai rata-rata sebesar 70,8; dan 3) ketuntasan belajar Fisika peserta didik kelas X MIA 1 SMA Negeri 1 Wonggeduku yang diajar dengan menggunakan model pembelajaran penemuan berbantuan simulasi PhET mengalami peningkatan, dimana pada siklus I persentase ketuntasan hasil belajar aspek kognitif sebesar $60 \%$ dan pada siklus II sebesar $84 \%$. Hal ini menunjukkan adanya peningkatan ketuntasan belajar sebesar $24 \%$.
\end{abstract}

Kata Kunci: Model Pembelajaran Penemuan, Simulasi PhET, Keterampilan Inkuiri, dan Hasil Belajar

\begin{abstract}
The research aims to: 1) know the description of inquiry skills students of class X MIA 1 SMAN 1 Wonggeduku in the subject matter taught parabolic motion with discovery learning based on PhET simulation; 2) knowing the magnitude of the increase in learning outcomes of students in class X MIA 1 of SMAN 1 Wonggeduku in the subject matter of parabolic motion taught by discovery learning using PhET simulation assisted; and 3 ) find out the description of the completeness of learning outcomes of class X MIA 1 students of SMAN 1 Wonggeduku on the subject matter of parabolic motion after being taught with a PhET simulation assisted discovery learning. This type of research is classroom action research (CAR) which has been carried out in 2 (two) cycles. The subjects in this study were all students of class X MIA 1 of SMAN 1 Wong in the 2018/2019 school year totaling 25 people. The data collected in this study were inquiry skills obtained from the observation sheet and learning outcomes obtained from the test results of cycle I and cycle II . Data analysis was performed descriptive statistics. From the data analysis we concluded that: 1) inquiry Skill of student class X MIA 1 SMAN 1 Wonggeduku in the subject matter parabolic motion through the use of discovery learning assisted PhET simulation. This is indicated by the average score of the aspects of inquiry skills of students in the first cycle and second cycle. Where the first cycle obtained an average score of 2.2 in the category enough and the second cycle obtained an average score of 3.3 which is in good category; 2) learning outcomes of student class $X$ MIA 1 SMAN 1 Wonggeduku taught using PhET simulation aided discovery learning in the subject matter parabolic motion increased. Shown in the first cycle values obtained an average of 61.8 and the second cycle is obtained an average value of 70.8; and 3) masteri learning Physics of students in class X MIA 1 SMA Negeri 1 Wonggeduku taught using discovery learning aided PhET simulation have increased, which in the first cycle the percentage of completeness of learning outcomes cognitive aspects of $60 \%$ and in the second cycle of $84 \%$. This indicates a $24 \%$ increase in learning completeness .
\end{abstract}




\section{PENDAHULUAN}

Proses pembelajaran yang optimal menjadi salah satu faktor pendukung dalam peningkatan hasil belajar dan keterampilan inkuiri peserta didik terhadap suatu materi pelajaran. Proses pembelajaran di kelas sejatinya menempatkan peserta didik sebagai subjek atau pusat dari pembelajaran (student center) dan bukan lagi sebagai objek dengan guru sebagai pengendali penuh. Guru selalu diarahkan untuk bisa melaksanakan proses pembelajaran yang membawa peserta didik untuk lebih aktif, kritis dan mandiri dalam mencari informasi, menganalisis fakta dan membuat hipotesis dari suatu materi yang sedang dipelajari.

Keterampilan inkuiri harus terus dilatih dan dikembangkan agar peserta didik dapat berpikir kreatif dalam memahami sains. Keterampilan inkuiri menekankan pada keterampilan peserta didik untuk merumuskan masalah berupa pertanyaan-pertanyaan yang bersifat ilmiah yang kemudian akan dilanjutkan dengan melakukan percobaan untuk memperoleh jawaban atas pertanyaan-pertanyaan yang ada. Peserta didik yang memiliki keterampilan inkuiri mampu untuk menemukan jawaban atas masalah-masalah yang diberikan kaitannya dalam memahami konsep, prinsip dan hukum sains yang dipelajari. Hal tersebut secara otomatis juga akan berdampak pada peningkatan hasil belajar peserta didik terkhusus pada aspek kognitif.

Peningkatan hasil belajar dan keterampilan inkuiri peserta didik terhadap suatu materi pelajaran dipengaruhi oleh beberapa faktor baik eksternal maupun internal. Salah satunya ialah proses pembelajaran yang berlangsung di dalam kelas. Guru dapat memberikan pengalaman belajar dengan mendesain proses pembelajaran yang melibatkan keterampilan berpikir peserta didik dan melibatkan proses menganalisis atas permasalahan yang diberikan. Fisika sebagai salah satu cabang ilmu sains memberikan tantangan tersendiri bagi peserta didik dalam menemukan berbagai solusi dari permasalahan yang diberikan berkaitan dengan konsep-konsep di dalamnya. Oleh karena itu, diperlukan penggunaan model pembelajaran yang tepat sebagai salah satu faktor yang kemudian dapat meningkatkan keterampilan inkuiri dan hasil belajar peserta didik.

Berdasarkan nilai ulangan harian peserta didik pada tahun ajaran 2017/2018 diperoleh bahwa kelas $\mathrm{X}$ MIA 1 memiliki persentasi kelulusan yang lebih rendah pada materi gerak parabola dibandingkan dengan materi lain dan kelas lain yang berada pada jenjang kelas X MIA. Dengan jumlah peserta didik 32 orang, hanya terdapat 12 orang yang memiliki nilai ulangan harian di atas 65 , selebihnya berada dibawah nilai 65 , jika dipersentasekan hanya $37,5 \%$ peserta didik yang memiliki nilai di atas Kriteria Ketuntasan Minimal (KKM). Berdasarkan nilai ulangan harian peserta didik tahun ajaran 2018/2019 kelas X MIA 1 dan MIA 2 pada materi gerak lurus diperoleh persentasi kelulusan untuk kelas X MIA 1 sebesar 52\% dari 25 orang jumlah peserta didik (13 orang) dan $75 \%$ untuk kelas $\mathrm{X}$ MIA 2 dari 24 jumlah peserta didik (18 orang).

Selain itu, berdasarkan hasil observasi awal pada tanggal 24 September 2018 di SMA Negeri 1 Wonggeduku Kelas X MIA 1 terhadap proses belajar-mengajar di dalam kelas, terlihat guru menampilkan sebuah video pembelajaran dan peserta didik diarahkan untuk menyimak video tersebut, setelah itu guru akan kembali menjelaskan materi yang ditampilkan dalam video pembelajaran tersebut jika masih ada peserta didik yang belum mengerti. Terlihat bahwa peserta didik kurang mengembangkan pemikiran dan analisisnya dalam mencari informasi yang berkaitan dengan materi yang sedang diajarkan, sebab mereka hanya diarahkan mengamati apa yang disampaikan dalam video pembelajaran tersebut.

Salah satu model pembelajaran yang dapat diterapkan adalah model pembelajaran berbasis penemuan (Discovery Learning). Menurut Borthick dan Jones (2000) menyatakan bahwa dalam pembelajaran penemuan (discovery), peserta didik belajar untuk mengenali masalah, mencari solusi, mencari informasi yang relevan, mengembangkan strategi solusi, dan melaksanakan strategi yang dipilih. Dalam kolaborasi pembelajaran penemuan, peserta didik turut aktif dalan komunitas praktek untuk memecahkan masalah bersama-sama. 
Dalam penelitian ini model pembelajaran penemuan dipilih dengan alasan lebih mendorong peserta didik untuk lebih aktif, kritis dan mandiri dalam memperoleh pengetahuannya sendiri. Sangat cocok bila digunakan pada keterampilan inkuiri, karena kegiatan dalam pembelajaran berbasis penemuan dapat memberikan pengalaman melakukan penyelidikan yang menggunakan aktivitas penemuan melalui penyelidikan seperti yang terdapat dalam keterampilan inkuiri.

Selain pemilihan model pembelajaran, penggunaan media atau alat bantu atau alat laboratorium dalam pembelajaran juga perlu diperhatikan. Terlebih saat ini masih sering dijumpai beberapa sekolah yang belum memiliki alat laboratorium yang lengkap. Perkembangan dan kemajuan teknologi yang sangat pesat saat ini, termasuk kehadiran komputer dan internet memungkinkan setiap peserta didik untuk belajar dan mengembangkan diri secara mandiri. Hasil teknologi berupa simulasi yang dapat diunduh secara gratis dan memungkinkan pembelajaran berlangsung di luar jam tatap muka dapat dimanfaatkan sebagai media pembelajaran. Saat ini terdapat beberapa aplikasi yang dapat dijadikan sebagai media pembelajaran berupa simulasi-simulasi konsep fisika yang kemudian dapat digunakan untuk mempelajari dan memahami lebih dalam mengenai konsep-konsep fisika. Salah satunya ialah simulasi PhET (Physics Education and Technology).

Septiani (2013) dalam skripsinya menjelaskan bahwa model pembelajaran penemuan berpengaruh signifikan terhadap peningkatan hasil belajar IPA-Fisika peserta didik. Kemudian Damayanti (2016) pada hasil penelitiannya menjelaskan bahwa model pembelajaran penemuan memberikan dampak kenaikan yang cukup signifikan terhadap aktivitas belajar dan hasil belajar Fisika peserta didik. Lidiana (2018) menjelaskan dalam hasil penelitiannya bahwa pembelajaran dengan menggunakan model discovery learning berbantuan simulasi $\mathrm{PhET}$ berpengaruh positif terhadap hasil belajar fisika kelas XI SMAN 1 Kediri.

\section{METODE}

Jenis penelitian ini adalah Penelitian Tindakan Kelas (PTK), yang dilakukan dengan menerapkan model pembelajaran penemuan berbantuan simulasi PhET sebagai alternatif tindakan untuk meningkatkan keterampilan inkuiri dan hasil belajar peserta didik Kelas X MIA 1 SMAN 1 Wonggeduku pada materi pokok gerak parabola. Penelitian ini dilakukan pada semester genap Tahun Ajaran 2018/2109 semester genap, bulan Januari-Februari tahun 2019 di SMAN 1 Wongeduku Desa Lambangi Kecamatan Wonggeduku Barat Kabupaten Konawe, Sulawesi Tenggara. Subjek penelitian ini adalah peserta didik Kelas X MIA 1 SMAN 1 Wonggeduku yang terdaftar pada semester genap Tahun Ajaran 2018/2019 dengan jumlah peserta didik 25 orang.

Penelitian ini merupakan penelitian tindakan kelas dengan proses pengkajian melalui sistem berdaur atau siklus (model Kurt Lewin) seperti di bawah ini. 


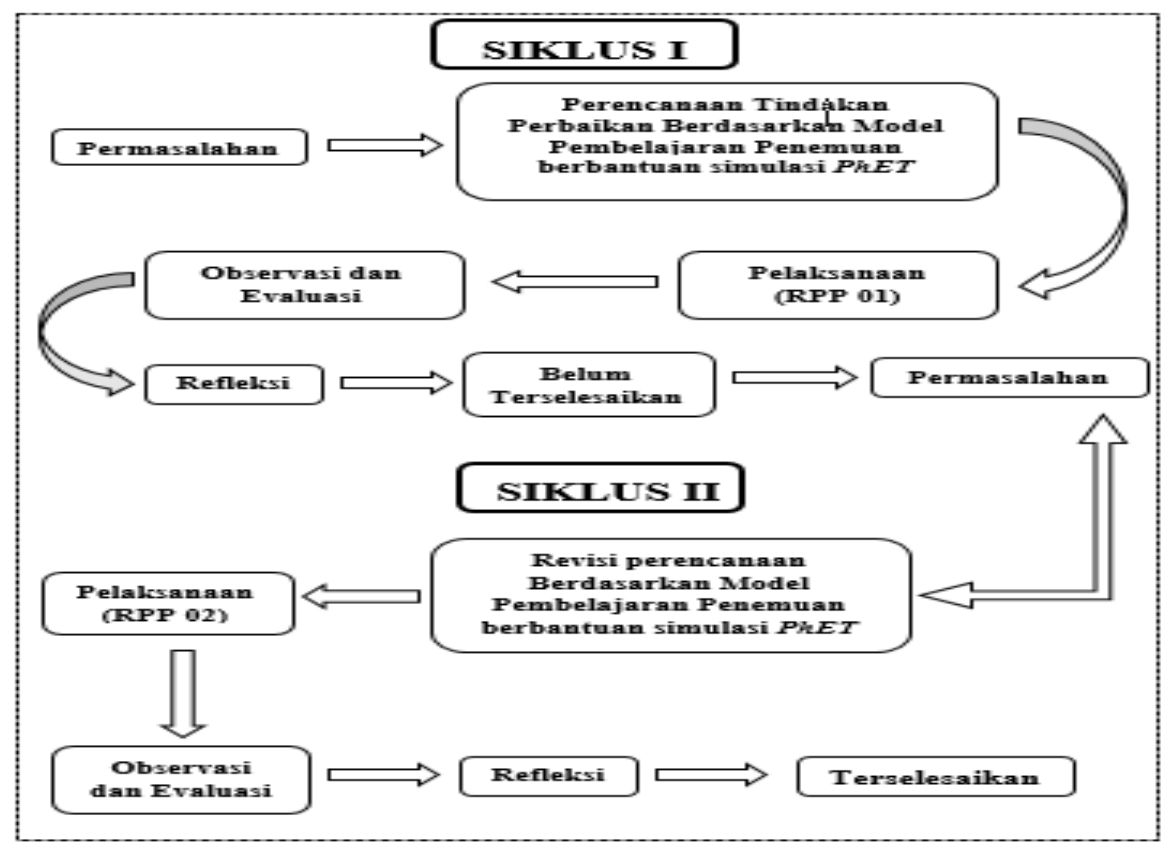

Gambar 1. Desain Penelitian Tindakan Kelas

Prosedur penelitian tindakan kelas ini dilakukan dalam dua siklus. Tiap siklus dilaksanakan sesuai dengan perubahan yang ingin dicapai, sesuai dengan yang telah didesain dalam faktor yang akan diselidiki. Untuk melihat sejauh mana pengetahuan dan pemahaman peserta didik pada materi gerak parabola. Dalam penelitian ini yang mengajar ialah peneliti yang berkolaborasi bersama guru mata pelajaran Fisika sebagai pengamat. Mengacu pada desain penelitian, maka prosedur penelitian tindakan kelas untuk tiap siklus meliputi permasalahan, penerapan model pembelajaran penemuan berbantuan simulasi PhET, pelaksanaan tindakan untuk siklus I (RPP 01) dan Siklus II (RPP 02), observasi, evaluasi, dan refleksi.

\section{HASIL DAN PEMBAHASAN}

\section{Deskripsi Hasil Penelitian}

\section{Keterampilan Inkuiri Peserta Didik}

Data mengenai keterampilan inkuiri peserta didik kelas X MIA 1 SMAN 1 Wonggeduku per kelompok selama pembelajaran dengan menggunakan model pembelajaran penemuan berbantuan simulasi PhET diambil dengan menggunakan lembar observasi dengan cara memberikan skor pada setiap aspek keterampilan inkuiri yang dilakukan oleh tiap kelompok sesuai dengan kriteria yang telah ditentukan. Data skor rata-rata keterampilan inkuiri tiap kelompok dalam proses pembelajaran pada siklus I dan siklus II dapat dilihat pada Tabel 1.

Tabel 1. Skor Rata-rata Keterampilan Inkuiri Kelompok Peserta Didik pada Siklus I

\begin{tabular}{clcc}
\hline No & \multicolumn{1}{c}{ Aspek-aspek yang diamati } & Skor & Kategori \\
\hline 1 & Merumuskan masalah & 2,6 & cukup \\
\hline 2 & Merumuskan hipotesis & 2,2 & cukup \\
\hline 3 & Melakukan percobaan & 2,2 & cukup \\
\hline 4 & Mengumpulkan data pengamatan & 2,0 & cukup \\
\hline 5 & Membuat kesimpulan & 1,8 & kurang \\
\hline Rata-rata keterampilan inkuiri peserta didik & & $\mathbf{2 , 2}$ \\
\hline Kategori & cukup \\
\hline
\end{tabular}


Dari Tabel 1 tersebut terlihat bahwa skor rata-rata keterampilan inkuiri tiap kelompok peserta didik pada siklus I adalah 2,2 dengan kategori cukup, dimana perolehan skor tertinggi terdapat pada indikator merumuskan masalah dengan skor ratarata sebesar 2,6 yang berada dalam kategori cukup dan skor terendah terdapat pada indikator membuat kesimpulan yakni 1,8 dengan kategori kurang, sedangkan indikator merumuskan hipotesis, melakukan percobaan, dan mengumpulkan data pengamatan memiliki skor rata-rata sebesar 2,2, 2,2, dan 2,0 yang masing- masing berada dalam kategori cukup, cukup, dan kurang.

\section{Aktivitas Guru}

Gambaran aktivitas guru dalam mengelolah pembelajaran dengan menggunakan model pembelajaran penemuan berbantuan simulasi PhET pada materi pokok gerak parabola diperoleh dengan menggunakan lembar observasi dengan cara memberikan skor pada setiap aspek aktivitas yang dilakukan oleh guru sesuai dengan kriteria yang telah ditentukan. Skor rata-rata aktivitas guru selama proses pembelajaran siklus I dan siklus II dapat dilihat pada Tabel 2.

Tabel 2. Skor Rata-rata Aktivitas Guru pada Siklus I dan Siklus II

\begin{tabular}{|c|c|c|c|c|c|}
\hline \multirow[b]{2}{*}{ No } & \multirow[b]{2}{*}{ Aktivitas yang Diamati } & \multicolumn{2}{|c|}{ Siklus I } & \multicolumn{2}{|c|}{ Siklus II } \\
\hline & & Skor & 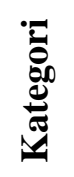 & Skor & 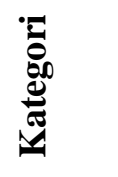 \\
\hline & \multicolumn{5}{|l|}{ A. Pendahuluan } \\
\hline & $\begin{array}{l}\text { 1. Guru membuka pelajaran dengan } \\
\text { mengucapkan salam dan berdoa sebelum } \\
\text { memulai pelajaran }\end{array}$ & 3 & $\mathrm{~B}$ & 3 & $\mathrm{~B}$ \\
\hline & $\begin{array}{l}\text { 2. Guru menyiapkan fisik dan psikis peserta } \\
\text { didik dalam mengawali kegiatan } \\
\text { pembelajaran }\end{array}$ & 3 & B & 4 & SB \\
\hline & $\begin{array}{llll}\text { 3. Guru mereview } & \text { kembali materi } \\
\text { sebelumnya }\end{array}$ & 3 & B & 4 & $\mathrm{SB}$ \\
\hline & $\begin{array}{l}\text { 4. Guru memberikan apersepsi dan motivasi } \\
\text { kepada peserta didik }\end{array}$ & 4 & SB & 4 & $\mathrm{SB}$ \\
\hline & 5. Guru menyampaikan tujuan pembelajaran & 3 & $\mathrm{~B}$ & 3 & $\mathrm{~B}$ \\
\hline & B. Kegiatan Inti & & & & \\
\hline \multirow{5}{*}{ II } & $\begin{array}{l}\text { 6. Guru membagi peserta didik dalam } \\
\text { beberapa kelompok belajar yang terdiri } \\
\text { atas } 5 \text { orang dalam masing-masing } \\
\text { kelompok }\end{array}$ & 4 & SB & 4 & $\mathrm{SB}$ \\
\hline & $\begin{array}{l}\text { 7. Guru memberikan stimulus atau } \\
\text { rangsangan }\end{array}$ & 3 & $\mathrm{~B}$ & 4 & B \\
\hline & $\begin{array}{l}\text { 8. Guru membagikan LKPD } \\
\text { menjelaskan tentang tugas yang akan } \\
\text { dikerjakan }\end{array}$ & 4 & SB & 4 & $\mathrm{SB}$ \\
\hline & $\begin{array}{l}\text { 9. Guru membimbing peserta didik untuk } \\
\text { membuat rumusan masalah dan hipotesis. }\end{array}$ & 4 & SB & 4 & $\mathrm{SB}$ \\
\hline & $\begin{array}{l}\text { 10. Guru membimbing } \\
\text { melakukan peserta didik } \\
\text { data dan informan /mengumpulkan } \\
\text { petunjuk dalam LKPD (Data Collection) }\end{array}$ & 3 & B & 3 & B \\
\hline
\end{tabular}


11. Guru membimbing peserta didik mengolah dan menganalisis data hasil percobaan serta mengerjakan LKPD berdasarkan hasil percobaan (Data Processing)

12. Guru membimbing peserta didik untuk melakukan diskusi mengenai hasil percobaan yang telah dilakukan

13. Guru memberikan kesempatan kepada peserta didik untuk memeriksa kembali jawaban dan membuktikan hipotesis yang telah diajukan (Fase Verifcation)

14. Guru meminta satu perwakilan peserta didik dalam setiap kelompok untuk mempresentasikan hasil percobaan dan 3

B
3 diskusinya secara bergantian

15. Guru memberikan penegasan jawaban terhadap hasil diskusi

2

C

B

$2 \quad \mathrm{C} \quad 3 \quad$ B

B

6. Guru mengumpulkan semua hasil diskusi dan membimbing peserta didik membuat kesimpulan tentang hasil percobaan/hasil 2

$\mathrm{C}$ 3 diskusi (Fase Generalization)

$\begin{array}{llll}3 & \text { B } & 4 & \text { SB }\end{array}$

SB

$\begin{array}{llll}3 & \text { B } & 3 & \text { B }\end{array}$

C. Kegiatan akhir

\begin{tabular}{llllll}
\hline III $\begin{array}{c}\text { 17. Guru bersama peserta didik meriview dan } \\
\text { menyimpulkan materi yang telah } \\
\text { dipelajari }\end{array}$ & 3 & B & 4 & SB \\
\hline $\begin{array}{c}\text { 18. Guru menyampaikan materi selanjutnya } \\
\text { dan mengucapkan salam }\end{array}$ & 3 & B & 4 & SB \\
\hline
\end{tabular}

\begin{tabular}{|c|c|c|c|c|c|}
\hline & D. Suasana Kelas & & & & \\
\hline \multirow{4}{*}{ IV } & 19. Peserta didik antusias & 3 & $\mathrm{~B}$ & 4 & SB \\
\hline & 20. Guru antusias & 3 & B & 4 & SB \\
\hline & 21. Waktu sesuai alokasi & 1 & K & 3 & B \\
\hline & $\begin{array}{l}\text { 22. KBM sesuai dengan langkah-langkah } \\
\text { pembelajaran dalam RPP }\end{array}$ & 3 & B & 3 & B \\
\hline & Rata-rata & \multicolumn{2}{|c|}{2,9} & \multicolumn{2}{|c|}{3,6} \\
\hline & Kategori & \multicolumn{2}{|c|}{ B } & \multicolumn{2}{|c|}{ SB } \\
\hline
\end{tabular}

\section{Hasil Belajar Peserta Didik}

Data mengenai hasil belajar Fisika peserta didik pada materi pokok gerak parabola yang diajar menggunakan model pembelajaran penemuan berbantuan simulasi PhET diambil dengan memberikan tes hasil belajar sebanyak 7 item setiap siklus. Hasil analisis deskriptif terhadap nilai hasil belajar yang diperoleh peserta didik kelas X MIA 1 di SMAN 1 Wonggeduku pada siklus I dan siklus II dapat dilihat pada Tabel 3. 
Tabel 3. Nilai Hasil Belajar Peserta Didik pada Siklus I dan Siklus II

\begin{tabular}{|c|c|c|c|c|c|}
\hline \multirow{2}{*}{ No } & \multirow{2}{*}{ Nama } & \multicolumn{2}{|c|}{ Siklus I } & \multicolumn{2}{|c|}{ Siklus II } \\
\hline & & Nilai & Keterangan & Nilai & Keterangan \\
\hline 1 & AS & 75,0 & $\mathrm{~T}$ & 86,5 & $\mathrm{~T}$ \\
\hline 2 & AA & 70,0 & $\mathrm{~T}$ & 78,0 & $\mathrm{~T}$ \\
\hline 3 & $\mathrm{D}$ & 65,8 & $\mathrm{~T}$ & 72,0 & $\mathrm{~T}$ \\
\hline 4 & DAP & 67,5 & $\mathrm{~T}$ & 69,0 & $\mathrm{~T}$ \\
\hline 5 & DP & 70,0 & $\mathrm{~T}$ & 78,0 & $\mathrm{~T}$ \\
\hline 6 & DM & 68,3 & $\mathrm{~T}$ & 72,0 & $\mathrm{~T}$ \\
\hline 7 & $\mathrm{~F}$ & 67,5 & $\mathrm{~T}$ & 73,0 & $\mathrm{~T}$ \\
\hline 8 & IK & 42,5 & BT & 50,0 & BT \\
\hline 9 & $\mathrm{I}$ & 65,0 & $\mathrm{~T}$ & 66,5 & $\mathrm{~T}$ \\
\hline 10 & KM & 48,3 & BT & 58,5 & BT \\
\hline 11 & $\mathrm{M}$ & 56,7 & BT & 70,0 & $\mathrm{~T}$ \\
\hline 12 & NRN & 65,8 & $\mathrm{~T}$ & 74,0 & $\mathrm{~T}$ \\
\hline 13 & PAS & 49,2 & $\mathrm{BT}$ & 67,0 & $\mathrm{~T}$ \\
\hline 14 & $\mathrm{RA}$ & 73,3 & $\mathrm{~T}$ & 82,0 & $\mathrm{~T}$ \\
\hline 15 & RDR & 65,0 & $\mathrm{~T}$ & 75,0 & $\mathrm{~T}$ \\
\hline 16 & $\mathrm{R}$ & 48,3 & $\mathrm{BT}$ & 62,0 & $\mathrm{BT}$ \\
\hline 17 & SR & 71,7 & $\mathrm{~T}$ & 78,5 & $\mathrm{~T}$ \\
\hline 18 & $\mathrm{~S}$ & 65,0 & $\mathrm{~T}$ & 76,5 & $\mathrm{~T}$ \\
\hline 19 & $\mathrm{~S}$ & 51,7 & BT & 67,5 & $\mathrm{~T}$ \\
\hline 20 & SNH & 66,7 & $\mathrm{~T}$ & 70,5 & $\mathrm{~T}$ \\
\hline 21 & $\mathrm{~W}$ & 70,8 & $\mathrm{~T}$ & 78,5 & $\mathrm{~T}$ \\
\hline 22 & YSAY & 63,3 & $\mathrm{~T}$ & 70,5 & $\mathrm{~T}$ \\
\hline 23 & YIS & 46,7 & BT & 58,0 & $\mathrm{BT}$ \\
\hline 24 & SR & 55,0 & BT & 69,5 & $\mathrm{~T}$ \\
\hline 25 & WST & 56,7 & BT & 66,5 & $\mathrm{~T}$ \\
\hline \multicolumn{2}{|c|}{ Rata-rata } & \multicolumn{2}{|c|}{61,8} & \multicolumn{2}{|c|}{70,8} \\
\hline \multirow{2}{*}{\multicolumn{2}{|c|}{$\begin{array}{c}\text { Standar Deviasi } \\
\text { Tuntas }(\%)\end{array}$}} & \multicolumn{2}{|c|}{8,9} & \multicolumn{2}{|c|}{7,8} \\
\hline & & \multicolumn{2}{|c|}{60} & \multicolumn{2}{|c|}{80} \\
\hline
\end{tabular}

4. Sinkronisasi Skor Keterampilan Inkuiri dan Hasil Belajar yang diperoleh Peserta didik

Data Sinkronisasi antara skor rata-rata belajar yang diperoleh peserta didik berdasarkan pembagian kelompok percobaan pada siklus I dan siklus II dapat dilihat pada Tabel 4. keterampilan inkuiri dan nilai rata-rata hasil

Tabel 4. Skor Rata-rata Keterampilan Inkuiri dan Nilai Rata-Rata Hasil Belajar Peserta Didik pada Siklus I dan Siklus II

\begin{tabular}{ccccc}
\hline \multirow{2}{*}{ Kelompok } & \multicolumn{4}{c}{ Rata-rata } \\
\cline { 2 - 5 } & \multicolumn{2}{c}{ Siklus I } & \multicolumn{2}{c}{ Siklus II } \\
\cline { 2 - 5 } & Inkuiri & Hasil Belajar & $\begin{array}{c}\text { Keterampilan } \\
\text { Inkuiri }\end{array}$ & Hasil Belajar \\
\hline 1 & 2,4 & 62,32 & 3,6 & 71,64 \\
\hline 2 & 2 & 60 & 3 & 67,8 \\
\hline 3 & 2,2 & 64,66 & 3,4 & 73,6 \\
\hline 4 & 2,4 & 60,18 & 3,2 & 70,4 \\
\hline 5 & 1,6 & 62 & 2,8 & 70,5 \\
\hline
\end{tabular}




\section{PEMBAHASAN}

Pelaksanaan penelitian tindakan kelas (PTK) dengan menggunakan model pembelajaran penemuan berbantuan simulasi PhET terdiri dari 2 siklus, dimana masing-masing siklus terdiri dari 1 kali pertemuan. Subjek dalam penelitian ini adalah peserta didik kelas X MIA 1 SMAN 1 Wonggeduku berjumlah 25 peserta didik yang terdiri dari 4 peserta didik laki-laki dan 21 peserta didik perempuan. Pada pelaksanaan pembelajaran tiap pertemuannya terdapat kegiatan yang mencerminkan ciri khas dari model pembelajaran penemuan antara lain di awal proses pembelajaran guru menyampaikan tujuan pembelajaran, memotivasi peserta didik, guru membagi peserta didik dalam beberapa kelompok yang beranggotakan 5 orang peserta didik setiap kelompok, guru menyajikan fenomena berupa animasi video maupun simulasi yang ditampilkan melalui PhET agar peserta didik dapat merumuskan masalah dan merumuskan hipotesis. Setelah itu guru mengarahkan peserta didik untuk mendapatkan informasi melalui percobaan dengan menggunakan simulasi PhET yang kemudian hasil percobaannya diolah, setelah itu guru mengarahkan peserta didik untuk mengecek benar dan tidaknya hipotesis yang telah dirumuskan berdasarkan hasil percobaan lalu membuat kesimpulan.

\section{Siklus I}

Siklus I dilaksanakan sesuai rencana yaitu satu kali pertemuan pada tanggal 23 Januari 2019. Pada pertemuan pertama yang dipelajari adalah sub materi pokok gerak dengan analisis vektor.

\section{Keterampilan Inkuiri Peserta Didik}

Berdasarkan hasil analisis deskriptif terhadap keterampilan inkuiri peserta didik pada siklus I menunjukkan perolehan skor rata-rata keterampilan inkuiri dari semua kelompok peserta didik sebesar 2,2 dengan kategori cukup, seperti yang terlihat pada Tabel 1. Masih terdapat aspek keterampilan inkuiri yang kurang yaitu membuat kesimpulan, juga dalam mengumpulkan data pengamatan peserta didik terkesan bingung dan kurang teliti sehingga masih terdapat beberapa kolom pada tabel data pengamatan yang tidak terisi, hal ini dikarenakan peserta didik belum terbiasa menggunakan simulasi PhET yang merupakan hal baru bagi mereka. Selain itu peserta didik juga tidak terbiasa mengerjakan LKPD dimana terdapat kegiatan merumuskan masalah, merumuskan hipotesis, melaksanakan percobaan, mengumpulkan data percobaan, dan membuat kesimpulan di dalamnya.

Solusi yang diupayakan yaitu guru harus lebih berusaha dalam membimbing peserta didik saat proses pembelajaran, mendekatkan diri kepada peserta didik untuk selalu bertukar informasi dan menanyakan masalah apa yang menjadi kendala pada saat pembelajaran berlangsung.

\section{Aktivitas Guru}

Berdasarkan hasil analisis deskriptif terhadap aktivitas guru pada siklus I diperoleh skor ratarata sebesar 2,9 dengan kategori baik. Dimana terdapat beberapa aspek aktivitas guru yang masih berada pada kategori cukup bahkan kurang. Aspek aktivitas guru yang berada pada kategori kurang adalah waktu sesuai alokasi, dimana pada pembelajaran di siklus I alokasi waktu pembelajaran yang digunakan guru masih belum sesuai dengan alokasi waktu yang seharusnya. Kurang maksimalnya aktivitas guru disebabkan guru belum sepenuhnya melaksanakan kegiatan pembelajaran sesuai dengan langkah-langkah model pembelajaran penemuan sehingga masih terdapat beberapa kekurangan dalam pelaksanaannya.

\section{Hasil Belajar Peserta Didik}

Rendahnya keterampilan inkuiri peserta didik dan aktivitas guru pada proses pembelajaran disiklus I juga berdampak pada hasil belajar yang diperoleh peserta didik. Jika diklasifikasikan masih terdapat 1 peserta didik yang memperoleh nilai hasil belajar dengan kategori sangat rendah dan 6 peserta didik yang berada pada kategori rendah. Selebihnya berada pada kategori sedang dan tinggi masing-masing sebanyak 8 dan 10 peserta didik.

Selain itu, standar deviasi yang diperoleh juga cukup tinggi menunjukkan nilai hasil belajar peserta didik masih rendah. Dari data nilai hasil belajar peserta didik menunjukkan persentase ketuntasan belajar yang diperoleh pada siklus I belum mencapai target penelitian yaitu mencapai ketuntasan belajar secara klasikal $75 \%$ seperti yang terlihat pada Tabel 4.3. Jumlah persentase ketuntasan belajar pada siklus I yang diperoleh secara klasikal yaitu $60 \%$ dari 25 jumlah peserta 
didik yang telah mencapai KKM yang ditentukan oleh sekolah yaitu $\geq 65$ dan $40 \%$ atau 10 peserta didik yang tidak mencapai KKM.

Berdasarkan hasil analisis deskriptif terhadap banyaknya persentase pesera didik yang belum mencapai standar KKM menunjukan adanya beberapa kekurangan dalam proses pembelejaran siklus I, diantaranya peserta didik yang belum terbiasa dengan model pembelajaran penemuan, peserta didik juga belum terbiasa dalam menggunakan simulasi PhET, kurangnya pengetahuan peserta didik dalam menggunakan operasi matematika yang benar ketika mengerjakan soal tes hasil belajar serta guru yang belum optimal membimbing dan mengarahkan peserta didik dalam proses pembelajaran terutama ketika peserta didik melakukan percobaan melalui simulasi PhET.

\section{Refleksi}

Dari masalah tersebut peneliti dan guru mata pelajaran melakukan analisis dan refleksi terhadap faktor-faktor yang menyebabkan kurangnya keterampilan inkuiri peserta didik, rendahnya nilai hasil belajar peserta didik serta beberapa aspek aktivitas guru dalam proses pembelajaran, antara lain sebagai berikut.

a) Peserta didik kurang memahami cara pengumpulan data yang benar dan tepat ketika melakukan percobaan melalui simulasi PhET.

b) Peserta didik kurang memahami cara membuat kesimpulan dari hasil percobaan yang diperoleh.

c) Guru masih kurang dalam membimbing dan mengarahkan peserta didik ketika melaksnakan percobaan melalui simulasi PhET.

d) Guru masih kurang dalam mengarahkan peserta didik untuk mengumpulkan data pengamatan melalui percobaan dengan simulasi PhET.

e) Guru masih kurang dakam mengarahkan peserta didik untuk membuat kesimpulan berdasarkan hasil percobaan.

f) Waktu pembelajaran masih belum sesuai alokasi.

Selanjutnya peneliti bersama guru juga menentukan langkah-langkah perbaikan untuk siklus II sebagai berikut. a) Guru harus menjelaskan lebih detail lagi dan memberi contoh tentang cara merumuskan masalah, merumuskan hipotesis dan merumuskan kesimpulan yang sesuai dan benar.

b) Guru mengarahkan dan membimbing peserta didik dalam melaksanakan percobaan melalui simulasi PhET dan mengumpulkan data pengamatan serta membuat kesimpulan pada LKPD sesuai dengan masalah dan tujuan percobaan secara terarah.

c) Guru harus memberikan contoh soal beserta penyelesaiannya termasuk operasi matematika yang terdapat di dalamnya.

d) Guru harus mengoptimalkan waktu pada saat proses pembelajaran agar setiap kegiatan pada saat proses pembelajaran dapat berjalan sebagaimana yang telah ditetapkan dalam RPP.

\section{Siklus II}

Siklus II dilaksanakan sesuai rencana yaitu satu kali pertemuan pada tanggal 2 Februari 2019. Pada pertemuan kedua yang dipelajari adalah sub materi pokok gerak parabola.

\section{Keterampilan Inkuiri}

Dari hasil analisis deskriptif pada siklus II menunjukkan adanya peningkatan keterampilan inkuiri peserta didik dari siklus I. Aspek-aspek keterampilan inkuiri yang pada siklus I berada pada kategori kurang dan cukup mengalami peningkatan yang lebih baik seperti yang terlihat pada Tabel 2, dengan perolehan skor rata-rata keterampilan inkuri sebesar 3,3 dengan kategori baik. Peningkatan rata-rata keterampilan inkuiri peserta didik menandakan bahwa kekurangan atau kelemahan-kelemahan yang terdapat pada siklus I dapat teratasi yang berdasarkan hasil refleksi dan perbaikan sehingga keterampilan inkuiri peserta didik dapat meningkat dari sebelumnya.

\section{Aktivitas Guru}

Aktivitas guru dalam mengelola pembelajaran juga mengalami peningkatan dari siklus I seperti yang terlihat pada Tabel 2. Aspek-aspek aktivitas guru yang sebelumnya pada siklus I berada pada kategori kurang dan cukup mengalami peningkatan pada siklus II sehingga berada pada kategori baik dan sangat baik. Hal ini 
menunjukkan pengelolaan pembelajaran yang dilakukan oleh guru telah sesuai dengan langkahlangkah model pembelajaran penemuan, dimana skor rata-rata yang diperoleh sebesar 3,6 dengan kategori sangat baik.

\section{Hasil Belajar}

Meningkatnya keterampilan inkuiri peserta didik dan aktivitas guru tersebut berdampak pada hasil belajar peserta didik. Berdasarkan hasil analisis deskriptif terhadap hasil belajar peserta didik pada siklus II untuk sub materi pokok gerak parabola mengalami peningkatan dari siklus I sebelumnya, seperti yang terlihat pada Tabel 3 . Jika diklasifikasikan nilai yang diperoleh peserta didik berada pada kategori sangat tinggi hingga rendah dan tidak ada lagi peserta didik yang memperoleh nilai dengan kategori sangat rendah. Standar deviasi yang diperoleh pun lebih kecil dibandingkan dengan siklus I. Hal ini menunjukkan peningkatan persentase ketuntasan belajar peserta didik yang telah mencapai ketuntasan secara klasikal sebesar $84 \%$ dari jumlah peserta didik 25 orang, yang artinya telah mencapai bahkan melewati target penelitian sebesar $75 \%$ ketuntasan secara klasikal.

Peningkatan keterampilan inkuiri peserta didik dan aktivitas guru serta hasil belajar peserta didik menunjukkan bahwa guru telah melakukan perbaikan berdasarkan analisis dan refleksi yang telah dilakukan sebelumnya. Selain itu, penggunaan simulasi PhET dalam proses pembelajaran membuat peserta didik terlihat lebih antusias dan aktif karena peserta didik tidak monoton hanya membaca buku dan melihat guru menjelaskan materi pembelajaran, tetapi juga dapat mencoba mencari informasi lebih banyak tentang materi gerak parabola secara mandiri.

Hal ini senada dengan pernyataan Resmiyanto (2009) yang menyatakan bahwa simulasi PhET merupakan animasi interaktif yang dibuat seperti layaknya permainan dimana peserta didik dapat belajar dengan melakukan eksplorasi. Simulasi-simulasi tersebut menekankan korespondensi antara fenomena nyata dan simulasi komputer kemudian menyajikannya dalam model konseptual fisis yang mudah dimengerti oleh para peserta didik. Dengan demikian, penggunaan simulasi PhET sangat mendukung peserta didik dalam memahami dan menemukan inti materi yang sedang dipelajarinya. Ditinjau dari hasil belajar yang diperoleh peserta didik untuk materi pokok gerak parabola pada tahun ajaran 2018/2019 lebih baik jika dibandingkan dengan hasil belajar yang diperoleh peserta didik pada tahun ajaran 2017/2018. Berdasarkan uraian di atas, dapat dikatakan bahwa penggunaan model pembelajaran penemuan berbantuan simulasi PhET di kelas X MIA 1 SMAN 1 Wonggeduku dapat meningkatkan keterampilan inkuri dan hasil belajar peserta didik pada materi pokok gerak parabola.

\section{KESIMPULAN}

Keterampilan inkuiri peserta didik kelas $\mathrm{X}$ MIA 1 SMAN 1 Wonggeduku pada materi pokok gerak parabola melalui penggunaan model pembelajaran penemuan berbantuan simulasi PhET mengalami peningkatan. Hal ini ditunjukkan dengan skor rata-rata aspek keterampilan Inkuiri peserta didik pada siklus I dan siklus II. Dimana pada siklus I diperoleh skor rata-rata sebesar 2,2 dan siklus II skor ratarata sebesar 3,3 yang berada pada kategori cukup. Hasil belajar aspek kognitif peserta didik kelas X MIA 1 SMAN 1 Wonggeduku yang diajar dengan menggunakan model pembelajaran penemuan berbantuan simulasi PhET pada materi pokok gerak parabola mengalami peningkatan hal ini ditunjukkan pada siklus I diperoleh skor ratarata sebesar 61,8, dan pada siklus II diperoleh skor rata-rata sebesar 70,8. Ketuntasan belajar Fisika peserta didik kelas X MIA 1 SMAN 1 Wonggeduku yang diajar dengan menggunakan model pembelajaran penemuan berbantuan simulasi PhET setiap siklus cenderung mengalami peningkatan, dimana pada siklus I persentase ketuntasan hasil belajar peserta didik sebesar $60 \%$ dan pada siklus II sebesar $84 \%$. Hal ini menunjukkan adanya peningkatan ketuntasan belajar sebesar $24 \%$.

\section{DAFTAR PUSTAKA}

Arikunto, S. 2005. Manajemen Penelitian Edisi Revisi. Jakarta: Rineka Cipta.

Arsyad, A. 2014. Media Pembelajaran. Jakarta: Rajawali Press. 
Bell, T., Urhahne, D., Schanze, S., dan Ploetzner, R. 2010. Collaborative Inquiry Learning: Models, tools, and challenges. International Journal of Science Education. Vol 32 No. 3.

Borthick, F., dan Jones, D. R. 2000. Motivation for Collaborative Online Learning Invention and Its Application in Information Systems Security Course. Issues in AccountingEducation. Vol.15 No. 2.

Damayanti, S. Q., Mahardika, I. K., dan Indrawati. Penerapan Model Discovery Learning Berbantuan Media Animasi Macromedia Flash disertai LKS yang Terintegrasi dengan Multirepresentasi dalam Pembelajaran Fisika di SMA. Universitas Jember. Vol. 4 No. 4.

Exploratorium. 2006. Process Skill. Exploratorium, San Francisco. Diakses melalui www.exploratorium.edu/ifi/workshops /fundamentals

Finkelstein, N. 2006. Hightech Tools For Teaching Physics: The Physics Education Technology Project. Merlot journal of online learning and teaching. Vol. 2 No. 3.

Hamiyah, N., dan Jauhar, M. 2014. Strategi Belajar Mengajar di Kelas. Jakarta:Prestasi Pustaka.

Indagiarmi, Y., dan Hakim, A. 2016. Pengaruh Model Pembelajaran Pembelajaran penemuan Terhadap Hasil Belajar Peserta didik Kelas XI Semester II Pada Materi Pokok Fluida Dinamik di SMA. UNIMED. Vol. 5 No. 1.

Lidiana, H., Gunawan., dan Taufik, M. 2018. Pengaruh Model Discovery Learning Bebantuan Media PhET terhadap Hasil Belajar Fisika Peserta Didik Kelas XI SMAN 1 Kediri Tahun Ajaran 2017/2018. Universitas Mataram. Vol. 4 No. 1.

Lunetta V,N., Hofstein A., dan Clough M. 2007. Learning and teaching in the school science laboratory: an analysis of research, theory, and practice. In $\mathrm{N}$, Lederman. and S. Abel (Eds,), Handbook of research on science education. Mahwah, NJ: Lawrence Erlbaum

Komyadi., dan Derlina. 2005 Penerapan Media Simulasi PhET untuk Meningkatkan Aktivitas Peserta didik pada Fase Pengumpulan Data Percobaan dan Mengolah serta Merumuskan Suatu Penjelasan dalam Model Pembelajaran Inquiri Training di SMA Negeri 5 Takengon. Medan: Universitas Negeri Medan.

Madlazim. 2007. Metode Praktis Mendesain Simulasi Fisika Interaktif. Surabaya: University Press UNESA.

Mustafa, M. I., dan Trudel, L. 2013. The Impact of Cognitive Tools on the Development of the Inquiry Skills of High School Students in Physics. International. Journal of Advanced Computer Science and Applications. Vol 4 No. 9.

Noeraida. 2016. Modul Guru Pembelajar. Jakarta: Pusat Pengembangan dan Pemberdayaan Pendidik dan Tenaga Kependidikan Ilmu Pengetahuan Alam (PPPPTK IPA).

Nurkhayati. 2003. Model Pembelajaran IPA dengan Starter Experimen Approach untuk meningkatkan keteampilan \& Pemahaman Konsep pada Murid Kelas V $S D$.Yogyakarta.

Pujianto., Supardianingsih., dan Chasanah, R. 2016. Buku Peserta didik Fisika Untuk SMA/MA Kelas X. Klaten: Intan Pariwara.

Purwanto, N. 2010. Prinsip-prinsip dan Teknik Evaluasi Pengajaran. Bandung: PT Remaja Rosdakarya.

Purwanto, C. E., Nugroho, S. E., dan Wijayanto. 2012. Penerapan Model Pembelajaran Guided Discovery pada Materi Pemantulan Cahaya untuk Meningkatkan Berpikir Kritis. Semarang: Universitas Negeri Semarang.

Ramly. 2006. Evaluasi Pendidikan dan Penilaian Hasil Belajar. Kendari: Universitas Haluoleo.

Rustaman, A. 2005. Pengembangan Kompetensi (Pengetahuan, keterampilan, Sikap, dan Nilai) Melalui Kegiatan Praktikum 
Biologi. Penelitian Jurusan Pendidikan Biologi FPMIPA UPI Bandung.

Selcuk, G. S. 2010. The effects of problem-based lerning on pre-service teachers'achievement, approaches and attitudes towards lerning physics. International Journal of the Physial Sciences. Vol. 5 No. 6.

Septiani, L. R. 2014. Pengaruh Model Guided Discovery Terhadap Keterampilan Proses Sains dan Hasil Belajar IPA-Fisika Peserta didik Kelas VII SMP Negeri 1 Jelbuk. Jember: Universitas Jember.

Soetjipo, B. F. 2001. Inquirias Methods of Implementating Active Learning. Jurnal Ilmu Pendidikan. Vol. 8 No.3. Malang: Universistas Negeri Malang.

Sudijono, A. 1996. Pengantar dan Evaluasi Pendidikan. Jakarta: Raja Gravindo.

Sugiarti. 2015. Pembelajaran Fisika Berbantuan Simulasi PhET dalam Membangun
Konsep Peserta didik. Jurnal Ilmu Kependidikan. Vol. 13 No. 1.

Sudjana. 2002. Metoda Statistika (Edisi Revisi). Bandung: Tarsito.

Sudjana, N. 2010. Penelitian Hasil Proses Belajar Mengajar. Bandung: PT. Remaja Rosdakarya.

Usman, M., dan Setiawati, L. 2001. Upaya Optimalisasi Kegiatan Belajar Mengajar. Bandung: PT. Remaja Rosdakarya.

Wicaksana, H., dan Mardiyana., Usodo, B. 2016. Eksperimentasi Model Pembelajaran Problem Based Learning (PBL) dan Discovery Learning (DL) dengan Pendekatan Saintifik pada Materi Himpunan ditinjau dari Adversity Quotient (Aq) Peserta Didik. Surakarta: Universitas Sebelas Maret Surakarta.

Winataputra, U. S. 2007. Teori Belajar dan Pembelajaran. Jakarta:Universitas Terbuka. 